咅
疣

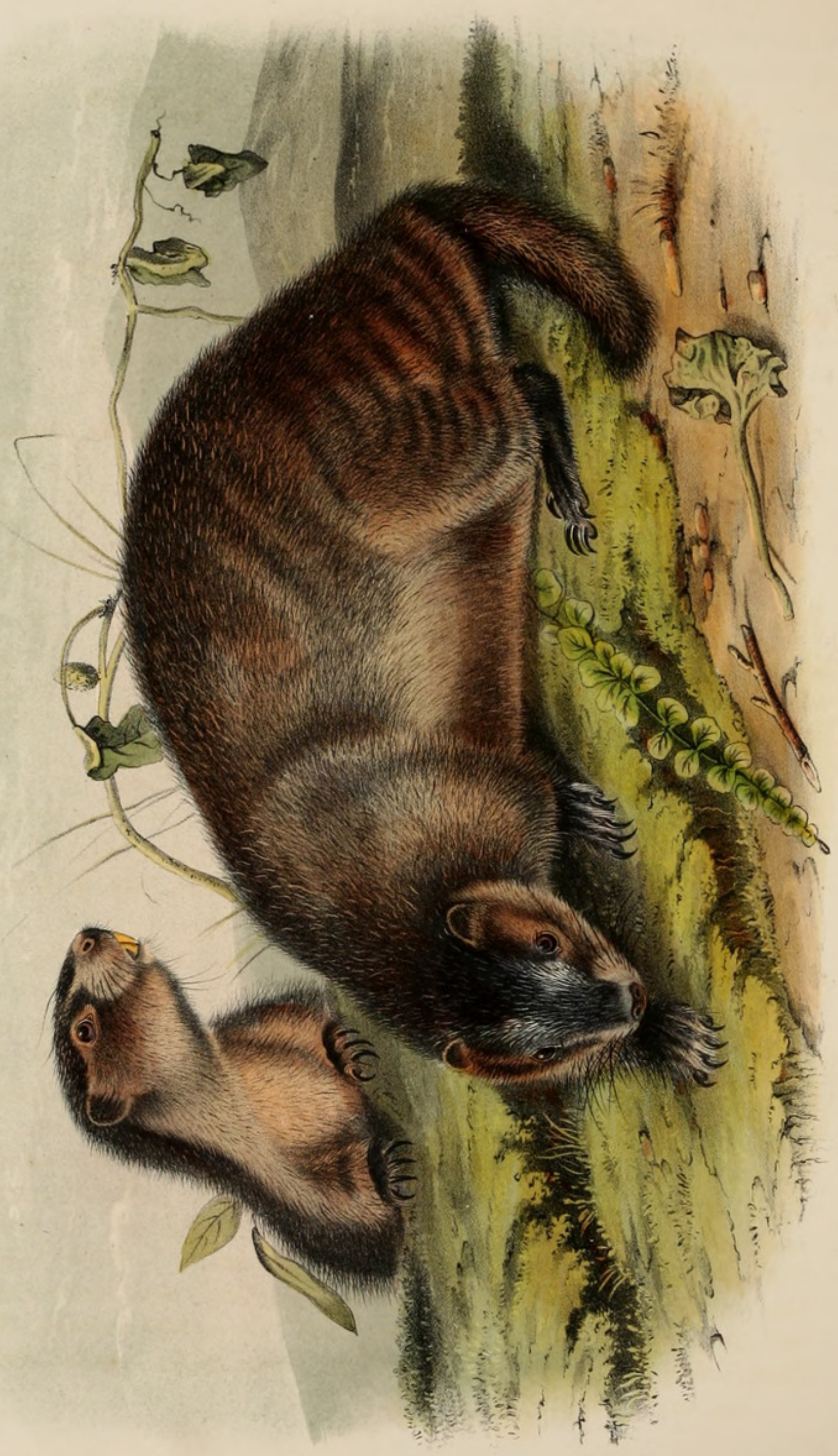

करें 


\title{
ARCTOMYS PRUINOSUS.-PENANT.
}

\author{
Hoary Marmot.-The Whistler. \\ P L A T E C III.-Males.
}

A. vellere cano longo, denso, maxime in thorace humorisque, in partibus posterioribus fulvo-flavescente, cauda comosa fusco nigriscente.

\section{CHARACTERS.}

Fur, long, dense, and hoary, particularly on the chest and shoulders; hinder parts dull yellowish-brown; tail bushy, blackish-brown.

\section{SYNONYMES.}

Hoary Marmot. Pennant, Hist. Quadr., vol. ii. p. 130.

" " " Arctic Zool., vol. i. p. 112.

Ground-Hog. Mackenzie's Voyage, p. 515.

Whistler. Harmon's Journal, p. 427.

Австомys (?) Pruinosus. Rich, Zool. Jour., No. 12, p. 518. Mar. 1828.

" $\quad$ Rich, Fauna Boreali Americana, p. 150.

Quisquis-QuI-Po. Cree Indians.

DEH-IE. Cheppewyans.

Souffleur, or Mountain-Badger. Fur-Traders.

Arotomys Proinosa. Harlan, Fauna, p. 169.

“ Calligata. Eschscholtz, Zoologischer Atlas, Berlin, 1829, pl. 6, part 2 , p. 1.

\section{DESCRIPTION.}

In form, this animal (which we examined whilst it was alive at the Zoological Gardens in London) bears a considerable resemblance to the European Marmot (.Arctomys .Marmota). It also resembles the Maryland Marmot (. . Monax). Being, at the time we saw it, excessively fat, the body, when it lay down, spread out or flattened like that of the badger; it was so covered with dense and very long hair that it was difficult to recognize the true outline; it subsequently shed its hair, and our figure was taken in its new and shorter pelage. The animal is rather longer than the Maryland Marmot; head, of moderate size; eyes, rather small but conspicuous; ears, oval and covered with hair on both surfaces; feet short, robust, and clothed with hair; nails strong, slightly arched, free; vOL. III. -3 
tail, short, and thickly clothed with long and coarse hair to the extremity The pelage is a soft and dense fur beneath, covered with longer and more rigid hairs.

\section{COLOUR.}

Fur on the back, dark at base, the outer portion white, with black points more or less extended; on the rump it is dull-brown at the roots, with black and yellow towards the extremities. The general appearance of the animal, owing to the admixture of these dark-brown and white hairs, of which the white predominate, is hoary-brown.

Upper surface of nose, ears, back part of the head, feet, and nails, black; a black band runs backwards from behind the ears for about an inch and a half, and then descends nearly vertically on the neck, where it vanishes; sides of muzzle, and behind the nostrils above, as well as chin, pure white; cheeks, grizzled with rust-colour and black; moustaches, nearly all black, a few, light-brown.

There are a few white hairs on the middle toes of the fore-feet; tail black, varied with rusty-brown, and a few whitish hairs with black points ; whole under parts pale rust colour, with a slight mixture of black on the belly ; extremities of the ears slightly tipped with white; upper incisors, yellow ; lower, nearly white.

\section{DIMENSIONS.}

Length from point of nose to root of tail,
"
" of tail (vertebræ),

HABITS.

This Marmot was described by Pennant, from a skin preserved in the Leverian Museum, which was for many years the only specimen in any known collection. It appears to have afterwards become a question whether there was such an animal, or whether it might not prove to be the 
Maryland Marmot, the original specimen, above mentioned, having been lost. Harlan says of it, "This specimen was supposed to have come from the northern parts of North America." Godman does not mention it. Dr. Richardson quotes Pennant's deseription, and states that he did not himself obtain a specimen; but "if correct" in considering it as the same as the Whistler of Harmon, "we may soon hope to know more of it, for the traders who annually cross the Rocky Mountains from Hudson's Bay to the Columbia and New Caledonia are well acquainted with it." $\mathrm{He}$ also mentions that one, (HARMox's Whistler, we presume) which was procured for him by a gentleman, was so much injured that he did not think it fit to be sent." The Doctor then gives the following account of it, and appears to have been quite correct in supposing it identical with the animal referred to by HARMon: "The Whistler inhabits the Rocky Mountains from latitude $45^{\circ}$ to $62^{\circ}$, and probably farther both ways : it is not found in the lower parts of the country. It burrows in sandy soil, generally on the sides of grassy hills, and may be frequently seen cutting hay in the autumn, but whether for the purpose of laying it up for food, or merely for lining its burrows, I did not learn. While a party of them are thus occupied, they have a sentinel on the lookout upon an eminence, who gives the alarm on the approach of an enemy, by a shrill whistle, which may be heard at a great distance. The signal of alarm is repeated from one to another as far as their habitations extend. According to Mr. HARMoN, they feed on roots and herbs, produce two young at a time, and sit upon their hind-feet when they give their young suck. They do not come abroad in the winter."

"The Indians take the Whistler in traps set at the mouths of their holes, consider their flesh as delicious food, and, by sewing a number of their skins together, make good blankets."

Our drawing of this Marmot was made from the specimen now in the museum of the Zoological Society of London, which is, we believe, the only one, even at this day, to be found in Europe, with the exception of a "hunter's skin" (i. e., one without skull, teeth, or legs), which was presented to the British Museum by Dr. Richardson, and was probably the one he refers to in the extract we have given above from the Fauna Boreali Americana. The specimen in the Zoological Museum is well preserved, the animal, which was alive when presented to the Society by B. King Esq., having died in the Menagerie (Zoological Gardens) in Regent's Park.

The living animal, when we observed it, seemed to be dull and sleepy. Its cage was strewed with grass and herbs, on which it had been feeding. 
GEOGRAPHICAL DISTRIBUTION.

The first specimen of this species was brought to England from Hudson's Bay. The specimen we have figured was obtained on Captain BACK's expedition. It inhabits the Rocky Mountains from $45^{\circ}$ to $62^{\circ}$, and will probably be found both to the north and south of these latitudes.

\section{GENERAL REMARKS.}

It is somewhat remarkable that an animal so large as the Hoary Marmot-so widely diffused throughout the fur countries, where it is seen by traders and hunters-should be so little known to naturalists. When the living animal was brought to the Zoological Gardens it excited much interest, as the existence of the species had for many years been doubted.

We spent an hour at the Museum of the Zoological Society in London with Dr. Richardson and Mr. Waterhouse, examining the specimen to which Eschscholz had given the name of $A$. Calligata; and we unanimously came to the conclusion that it was the $A$. Pruinosus. 

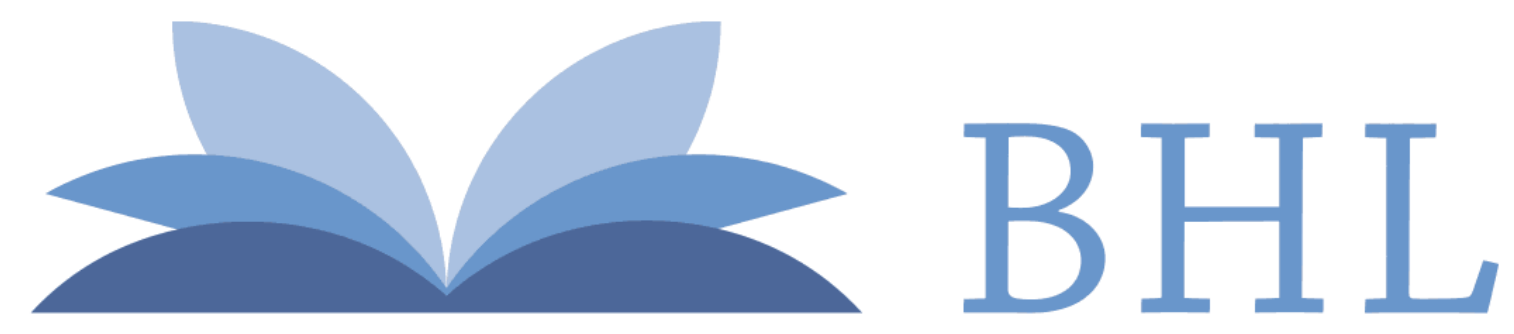

\section{Biodiversity Heritage Library}

Audubon, John James and Bachman, John. 1854. "Arctomys pruinosus, Hoary Marmot- The Whistler [PI. CIII, males]." The quadrupeds of North America 3, 17-20. https://doi.org/10.5962/p.322353.

View This Item Online: https://www.biodiversitylibrary.org/item/108515

DOI: https://doi.org/10.5962/p.322353

Permalink: https://www.biodiversitylibrary.org/partpdf/322353

\section{Holding Institution}

Duke University Libraries (archive.org)

\section{Sponsored by}

Duke University Libraries

\section{Copyright \& Reuse}

Copyright Status: Not provided. Contact Holding Institution to verify copyright status.

This document was created from content at the Biodiversity Heritage Library, the world's largest open access digital library for biodiversity literature and archives. Visit BHL at https://www.biodiversitylibrary.org. 